\title{
From Model Farm \\ to a College with Students: Benjamin Gue, Peter Melendy, Adonijah Welch, and the Iowa Agricultural College and Model Farm, 1867-1869
}

\author{
EDWARD A. GOEDEKEN
}

THE IOWA AGRICULTURAL COLLEGE AND MODEL FARM was officially established in 1858, but by 1868 it still had no students, no faculty, and no president. Until those three components were in place, the fledgling institution residing on a windswept plain in western Story County would continue to function only as a 648-acre farmstead with some livestock, fencing, and small plots of row crops. But change was stirring. After the interruption of the Civil War, construction on the Main (or College) building began in the spring of 1865; three years later it was nearly complete. ${ }^{1}$ The time had finally arrived for the college to begin its educational mission. The next step would be to acquire a president, design a curriculum, and hire some faculty.

1. On the early history of the college, see Mary E. Atherly, Farm House: College Farm to University Museum (Ames, 1995), 29-63; Pamela Riney-Kehrberg, "Foundations of the People's College: The Early Years of Iowa State," in Dorothy Schwieder and Gretchen Van Houten, eds., A Sesquicentennial History of Iowa State University: Tradition and Transformation (Ames, 2007), 11-32; and Tanya ZanishBelcher, "Early Research Efforts at Iowa Agricultural College and Model Farm, 1858-1905," in The Land-Grant Act and the People's College, Iowa State University

THE ANNALS OF IOWA 75 (Spring 2017). (C) State Historical Society of Iowa, 2017. 
The burden of accomplishing that challenging task would fall primarily upon three individuals: Benjamin Gue and Peter Melendy, members of the college's board of trustees, and Adonijah Welch, the college's first president. Those three men would need to resolve a basic question: What kind of college would they create? How Gue, Melendy, and Welch answered that question is the subject of this article.

THAT THE COLLEGE in Ames would finally become a functioning school was the result of a combination of events a few years earlier. The secession of the southern states in the spring of 1861, along with the election of a president more sympathetic to government assistance to higher education, enabled Senator Justin Morrill of Vermont to succeed on his second try at getting his land-grant legislation passed and signed into law. On July 2, 1862, Abraham Lincoln placed his signature at the bottom of what became known as the Morrill Land-Grant Act. With it a new type of college was born, one that would change forever the role of the federal government in higher education. These new institutions reflected the egalitarian spirit that had begun to flourish during the Jacksonian Era. For each of these new schools, one could say, as Willis Rudy observed, "Its main standards were quantitative, its main concerns materialistic, its educational bias utilitarian, and its outlook optimistic." 2

(Ames, 2011), ed. Allison H. Sheridan, 43-59. An unpublished history of the college by Louis B. Schmidt titled "The Iowa State College of Agriculture and Mechanic Arts, 1851-1891," probably produced in the early 1920s and lacking citations, is in box 3, Louis B. Schmidt Papers, University Archives, Iowa State University Library, Ames. Schmidt published two shorter versions in "Origin and Establishment of Iowa State," Alumnus 24 (1929), 215-18, and "Origin and Establishment of the College," Alumnus 28 (1933), 187-95. Also useful are Christie Dailey, "Implementation of the Land-Grant Philosophy during the Early Years at Iowa Agricultural College, 1858-1890" (master's thesis, Iowa State University, 1982); and Charles Bessey, "Laying the Foundations," Annals of Iowa 9 (1909), 26-44. For general histories of the college, see Earle D. Ross, A History of The Iowa State College of Agricultural and Mechanic Arts (Ames, 1942), and a shorter version, The Land-Grant Idea at Iowa State College: A Centennial Trial Balance, 1858-1958 (Ames, 1958).

2. Willis Rudy, “The 'Revolution' in American Higher Education-1865-1900," Harvard Educational Review 21 (1951), 163. For the role of the federal government in land-grant universities, see Hunter A. Dupree, Science in the Federal Government: A History of Policies and Activities (Baltimore, 1986). 
The story of how these institutions came to be has spawned an extensive historiography over the past century, with several generations of historians applying their interpretive skills toward crafting an understanding of what has commonly been called the "land-grant movement." Beginning with Earle Ross in the 1940s and culminating with recent scholarship by Nathan Sorber, Roger Geiger, and others, the quest for understanding this important aspect of American educational history continues apace. ${ }^{3}$

For historians of the land-grant movement, the forces leading up to the eventual passage of the Morrill Act represent a complex web of interrelated actions. From the nation's earliest years, its leaders expressed an interest in science and agriculture. As the country expanded, more Americans supported greater educational opportunities for average citizens. Meanwhile, in some states, reform-minded citizens began clamoring for the creation of schools whose chief focus would be on topics relating to agriculture. Part of the agitation for these schools came from the burgeoning agricultural press and part came from the rise of agricultural societies that began flourishing in the second decade of the nineteenth century. ${ }^{4}$

3. Prominent titles in the land-grant movement historiography include Earle D. Ross, Democracy's College: The Land-Grant Movement in the Formative Stage (Ames, 1942); Edward Danforth Eddy Jr., Colleges for Our Land and Time: The Land-Grant Idea in American Education (New York, 1956); Allan Nevins, The State Universities and Democracy (Urbana, IL, 1962); J. B. Edmond, The Magnificent Charter: The Origin and Role of the Morrill Land-Grant Colleges and Universities (Hicksville, NY, 1978); Roger L. Williams, The Origins of Federal Support for Higher Education: George W. Atherton and the Land-Grant College Movement (University Park, PA, 1991); Roger L. Geiger, "The Era of the Multipurpose Colleges in American Higher Education, 1850-1890" and "The Rise and Fall of Useful Knowledge: Higher Education for Science, Agriculture, and the Mechanic Arts, 1850-1875," in The American College in the Nineteenth Century, ed. Roger L. Geiger (Nashville, TN, 2000), 127-52, 153-68; and Nathan Sorber, "Creating Colleges of Science, Industry, and National Advancement: The Origins of the New England LandGrant Colleges," in The Land-Grant Colleges and the Reshaping of American Higher Education, ed. Roger Geiger and Nathan Sorber (New Brunswick, NJ, 2013), 4171. Two recent valuable works are Roger Geiger, The History of American Higher Education: Learning and Culture from the Founding to World War II (Princeton, NJ, 2015), especially chap. 7 (pp. 269-314), which is devoted to land-grant colleges; and Alan I Marcus, ed., Science as Service: Establishing and Reformulating LandGrant Universities, 1865-1930 (Tuscaloosa, AL, 2015).

4. For a review of one prominent nineteenth-century Iowa agricultural newspaper, see Elaine Harvey Edwards, "Iowa's Early Agricultural Press: A Content Analysis 
In 1819 Simeon De Witt, surveyor-general of the state of New York, published a pamphlet outlining the need for a new college devoted to agriculture. A few years later, in 1823, the Gardiner Lyceum in Maine became the earliest American school focused on agriculture. In 1846 the Farmers' College, near Cincinnati, Ohio, started instruction, and in the following decade Michigan and Pennsylvania started their own schools with the nearly simultaneous creation of Michigan's Agricultural College and Pennsylvania's Farmers' High School, both in February 1855. These efforts were followed by the construction of schools in Maryland, chartered in 1856 and opened in 1859, and in Iowa, where the state legislature allotted $\$ 10,000$ to establish the Iowa State Agricultural College and Model Farm in 1858. ${ }^{5}$

By the 1830s and 1840s, steady population increase, as well as a wealth of new inventions, were changing the country's infrastructure and fostering the need for education that was useful for the many, not just for the few. ${ }^{6}$ The spread of canals, railroads, roads, and the telegraph spurred a demand for people with technical skills. The antebellum college, designed for the most part as

of the Iowa Farmer and Horticulturalist, 1853-1856" (master's thesis, Iowa State University, 1994). A general history of agricultural societies can be found in Donald B. Marti, To Improve the Soil and the Mind: Agricultural Societies, Journals, and Schools in the Northeastern States, 1791-1865 (Ann Arbor, MI, 1979). An overview of efforts to promote agriculture can be found in Margaret W. Rossiter, "The Organization of Agricultural Improvement in the United States, 1785-1865," in Alexandra Oleson and Sanborn C. Brown, eds., The Pursuit of Knowledge in the Early American Republic: American Scientific and Learned Societies from Colonial Times to the Civil War (Baltimore, 1976), 279-98. Agricultural societies were also strong proponents of state and local fairs. For a recent history of the state fair in Iowa, see Chris Rasmussen, Carnival in the Countryside: The History of the Iowa State Fair (Iowa City, 2015).

5. Good overviews can be found in Alfred Charles True, A History of Agricultural Education in the United States, 1785-1925 (Washington, DC, 1929), 23-94; and L. H. Bailey, ed., Cyclopedia of American Agriculture, vol. 4, Farm and Community (New York, 1909), 355-422.

6. For more on the utility of education, see Roger L. Geiger, "The Rise and Fall of Useful Knowledge: Higher Education for Science, Agriculture, and the Mechanic Arts, 1850-1875," History of Higher Education Annual 18 (1998), 47-65. Also informative is Paul Nienkamp, "Land-Grant Colleges and American Engineers: Redefining Professional and Vocational Engineering Education in the American Midwest, 1862-1917," American Educational History Journal 37 (2010), 313-30. This essay comes from his larger work, "A Culture of Technical Knowledge: Professionalizing Science and Engineering Education in Late-Nineteenth Century America" (Ph.D. diss., Iowa State University, 2008). 
a place for religious training, appeared ill-suited to meet these new technical demands. ${ }^{7}$ Still, the established colleges, especially Harvard and Yale, recognized the impact of scientific advances, and each school established a separate space for such study: the Sheffield Scientific School at Yale and the Lawrence Scientific School at Harvard. These schools had been preceded by the United States Military Academy (1802), with its focus on engineering instruction, and also by the earliest technical college, the Polytechnic Institute, founded by Stephen Rensselaer at Troy, New York, in $1824 .{ }^{8}$

New developments in agricultural scientific research were reflected in the 1840 publication of Justus Liebig's influential book, Organic Chemistry in its Applications to Agriculture and Physiology. Liebig's research showed that a plant's roots absorbed ions of nitrate, phosphate, potassium and calcium. Thus soil fertility could be maintained permanently through a careful balancing of nutrients. ${ }^{9}$ The application of careful scientific research that would in turn enhance agricultural productivity was exciting to nineteenth-century agriculturalists who were becoming increasingly alarmed about American soils that were in danger of wearing out and becoming useless for cultivation.

All of these forces began to crescendo during the 1840s and early 1850s and started coalescing around a political and legislative solution that many believed would need to come from Washington, D.C. In the antebellum period the federal government had gotten in the habit of providing land for schools. Both

7. For an understanding of science in the pre-Civil War college curriculum, see Stanley M. Guralnick, Science and the Ante-Bellum American College (Philadelphia, 1975). A more general assessment is Robert V. Bruce, The Launching of Modern American Science, 1846-1876 (New York, 1987).

8. John S. Brubacher and Willis Rudy, Higher Education in Transition: A History of American Colleges and Universities, 4th ed. (New Brunswick, NJ, 1997), 61-62. For an overview of nineteenth-century technological developments, see Todd Timmons, Science and Technology in Nineteenth-Century America (Westport, CT, 2005). Also valuable is Charles R. Morris, The Dawn of Innovation: The First American Industrial Revolution (New York, NY, 2012).

9. Liebig's work is explained in Margaret W. Rossiter, The Emergence of Agricultural Science: Justus Liebig and the Americans, 1840-1880 (New Haven, CT, 1975). For more on the European influences on agricultural scientific education, see Mark R. Finlay, "Transnational Exchanges of Agricultural Scientific Thought from the Morrill Act through the Hatch Act," in Marcus, ed., Science as Service, 33-60. 
the Land Ordinance of 1785 and the 1787 Northwest Territory Ordinance had set aside township grants to support primary schools. In the 1830s Congress also allowed for land to be set aside to establish a state university within a given territory. ${ }^{10}$ By the early 1850s, the idea that Congress should do more for the industrial classes began to bear fruit. One of the idea's leading proponents was Jonathan Turner, an Illinois educator whose speeches and writings advocated granting public lands for the creation of colleges that would be separate from the existing classical colleges and provide an equal education for "the industrial classes, including all the cultivators of the soil, artisans, mechanics, and merchants." 11

Turner's suggestions, along with those of many others, were swirling around Washington, D.C., by the time Justin Morrill showed up as a new congressman in 1855 . Morrill was a successful businessman who had retired young and entered politics. He represented Vermont's second congressional district from 1855 to 1867 and then served as senator from 1867 until his death in 1898. Although his formal schooling was limited, he retained an avid interest in education for the common person throughout his legislative career. In December 1857, during his first term as congressman, he introduced a bill that would authorize Congress to grant lands to support the establishment of agricultural colleges.

10. For more on this early land-grant legislation, see David Tyack, Thomas James, and Aaron Benavot, Law and the Shaping of Public Education, 1785-1954 (Madison, WI, 1987); and Harold M. Hyman, American Singularity: The 1787 Northwest Ordinance, the 1862 Homestead and Morrill Acts, and the 1944 G.I. Bill (Athens, GA, 1986). Older, but still useful, is Frank W. Blackmar, "The History of Federal and State Aid to Higher Education in the United States," Bureau of Education, Circular of Information, no. 1 (1890), 3-343. Sarah Phillips sets the landgrant bill within a larger context in "Antebellum Agricultural Reform, Republican Ideology, and Sectional Tension," Agricultural History 74 (2000), 799-822. A helpful historical perspective is provided by George Donald Merrill, "Land and Education: The Origin and History of Land Grants for the Support of Education" (Ph.D. diss., University of Southern California, 1965). Nathan Sorber and Roger Geiger summarize the land-grant law's historiography in "The Welding of Opposite Views: Land-Grant Historiography at 150 Years," in Higher Education: Handbook of Theory and Research, ed. M. B. Paulsen, vol. 29 (2014), 385-422.

11. J. B. Turner, Industrial Universities for the People (Jacksonville, IL, 1853), 16. For an account that promotes Turner's influence on the passage of the Morrill Act, see Edmund J. James, "The Origin of the Land Grant Act of 1862 (The SoCalled Morrill Act) and Some Account of its Author Jonathan B. Turner," University Studies, University of Illinois 4 (1910), 7-139. 
Both houses of Congress passed Morrill's bill by early 1859, but President James Buchanan promptly vetoed it on the grounds that it was inexpedient and unconstitutional. With the election of Abraham Lincoln in 1860 and the resulting departure of the southern states' congressmen, Morrill shrewdly reintroduced his bill in December 1861. On this second attempt in June 1862, it was passed again by both houses, and Lincoln signed it into law on July $2 .{ }^{12}$

The land-grant act provided each state with 30,000 acres of public land for each of its representatives and senators in Congress, which made Iowa eligible to receive 240,000 acres. If a state no longer held any public lands, it received land scrip, or landprocurement certificates, which it could use to obtain land from another state. A small portion of the revenue from the sale of that land could be used to purchase ground for the college, but none of the money could be used to construct buildings - the states would have to provide that funding. The crux of the act was contained in section 4, which outlined the legislation's prime purpose.

Each state may take and claim the benefits of the Act to the endowment, support, and maintenance of at least one college, where the leading object shall be, without excluding other scientific and classical studies, and including military tactics, to each such branches

12. Biographies of Morrill include William Belmont Parker, The Life and Public Services of Justin Smith Morrill (Boston, 1924.) A more modern treatment is Coy F. Cross II, Justin Smith Morrill: Father of the Land-Grant Colleges (East Lansing, MI, 1999). For a close review of the land-grant legislation, see Randal Leigh Hoyer, "The Gentleman from Vermont: The Career of Justin S. Morrill in the United States House of Representatives" (Ph.D. diss., Michigan State University, 1974); and Lee Stewart Duemer, "The Origins of the Morrill Land Grant Act of 1862: A Convergence of War and the Threat of War, Agricultural Influence, Modernization, and the American University Movement" (Ph.D. diss., University of Pittsburgh, 1996). For historical background, see Scott Allen Key, "The Origins of American Land Grant Universities: An Historical Policy Study" (Ph.D. diss., University of Illinois at Chicago, 1995). Earle Ross provides a good assessment of Morrill's contribution in "The 'Father' of the Land-Grant College," Agricultural History 12 (1938), 151-86. For the views of western states on the act, see Paul Wallace Gates, "Western Opposition to the Agricultural College Act," Indiana Magazine of History 37 (1941), 103-36. For the political context, see Leonard P. Curry, Blueprint for Modern America: Nonmilitary Legislation of the First Civil War Congress (Nashville, TN, 1969); and Williamjames Hull Hoffer, To Enlarge the Machinery of Government: Congressional Debates and the Growth of the American State, 1858-1891 (Baltimore, MD, 2007). For the economic aspects of the act, see Scott Key, "Economics or Education: The Establishment of American LandGrant Universities," Journal of Higher Education 67 (1996), 196-220. 
of learning as are related to agriculture and the mechanic arts in such a manner as the legislatures of the states may respectively prescribe in order to promote the liberal and practical education of the industrial classes in the several pursuits and professions in life. ${ }^{13}$

Morrill was deliberately vague in describing what exactly should be taught at these new schools. Asserting that the "leading object" should be agriculture and the mechanic arts, he also insisted that "other scientific and classical studies" not be excluded from the curriculum. Military tactics was added to the language of the earlier version in recognition of the difficulties experienced by the Army of the Potomac during the first two years of the Civil War. Morrill left up to the individual states the responsibility of determining exactly what should and should not be taught "in order to promote the liberal and practical education of the industrial classes in the several pursuits and professions in life." It would take several decades for individual institutions to establish a curricular balance between "liberal and practical" education. ${ }^{14}$

Iowa was the first state to agree to the conditions of the Morrill Act. The state legislature did so on September 11, 1862. ${ }^{15}$ The Iowa Agricultural College and Model Farm (IAC) had been officially established four years earlier in $1858 .{ }^{16}$ With little money

13. The official version of the act is "An Act Donating Public Lands to the Several States and Territories which May Provide Colleges for the Benefit of Agriculture and the Mechanic Arts," chap. 130, 12 Stat. 503, 7 U.S.C.301 et. seq.

14. For a summary analysis of section 4 of the act, see Edmond, The Magnificent Charter, 17-18; and Eddy, Colleges for Our Land and Time, 32-45. For a list of the land-grant schools that accepted the grant and their starting dates, see G. Lester Anderson, ed., Land-Grant Universities and Their Continuing Challenge (Lansing, MI, 1976), appendix, table 2. For chronological details, see Henry S. Brunner, Land-Grant Colleges and Universities, 1862-1962 (Washington, DC, 1962). Also valuable is Benjamin F. Andrews, "The Land Grant of 1862 and the Land-Grant Colleges," Department of the Interior, Bureau of Education Bulletin no. 13 (1918), 363. Henry F. French, president of the Massachusetts Agricultural College, provided an assessment of agricultural education soon after the act passed; his report is in Report of the Commissioner of Agriculture for the Year 1865 (Washington, DC, 1866), 137-86. French also included information about agricultural schools in France, Germany, and England.

15. 1862 Laws of Iowa, chap. 26; 1863 Laws of the State of New York, chap. 460.

16. 1858 Laws of Iowa, chap. 91. Gue's speech in support of the legislation is in box 2, Benjamin Gue Papers, State Historical Society of Iowa, Des Moines (SHSIDM). Earlier calls for an agricultural college included William Duane Wilson, "Plan of an Agricultural School," Iowa Farmer and Horticulturist, June 1856, 11-12; 
from a legislature burdened with supporting the Union cause during the Civil War, IAC remained more of a model farm than a college for its first decade. But with the conclusion of the Civil War and the construction of the new Main Building, the college's trustees turned to the essential task of creating a real college with students, faculty, and a curriculum. This is where Benjamin F. Gue and Peter Melendy enter the story.

BENJAMIN GUE spent much of his life in the state's political sphere as an Iowa legislator, lieutenant governor, and newspaper publisher. Yet he considered his labors on behalf of the Iowa Agricultural College to be his "most worthwhile accomplishment." 17 Gue was born in 1828 into a devout Quaker family in Green County in eastern New York. In 1831 his family moved to a Quaker settlement in western New York. After a stint at teaching, Gue and his brother Joseph set out for Iowa in 1852 and purchased a small farm in Scott County. Benjamin's Quaker heritage influenced his antislavery passions, and he soon got involved in local politics. In 1856 he helped organize the nascent Iowa Republican Party and the next year found himself elected to the lower house of the Iowa General Assembly. ${ }^{18}$

and Suel Foster, "Agricultural School," Iowa Farmer and Horticulturist, 8/15/1857, 70. For alternative views of the need for agricultural education in Iowa, see Mildred Throne, "'Book Farming' in Iowa, 1840-1870," Iowa Journal of History 49 (1951), 117-42.

17. Katherine Gue Leonard to Wallace Barron, 4/8/1958 and 4/16/1958, Katherine Gue Leonard file, box 3, Wallace E. Barron Papers, University Archives, Iowa State University Library, Ames. For biographical information on Gue, see David C. Mott, "Benjamin F. Gue," Annals of Iowa 20 (1937), 603-631; Johnson Brigham, "Notable Deaths," Annals of Iowa 6 (1904), 476-77. Also useful is Earle D. Ross's introduction to Diary of Benjamin F. Gue in Rural New York and Pioneer Iowa, 1847-1856 (Ames, 1962). Gue's daughter, Katherine Gue Leonard, provides a short synopsis of his life and career in her "Notes on the Life of Benjamin F. Gue, 1828-1904," folder 1 (Biographical Materials, 1865-1959), box 1, Benjamin F. Gue Papers, University Archives, Iowa State University Library, Ames. Gue's obituary is in the Des Moines Register and Leader, 6/2/1904. According to L. Glenn Smith, Teacher Education at Iowa State University, 1868-1982 (Ames, 1982), 7, Gue's name was pronounced like "way."

18. For the context for Gue's political activities, see Lowell J. Soike, Busy in the Cause: Iowa, the Free-State Struggle in the West, and the Prelude to the Civil War (Lincoln, NE, 2014); and Robert R. Dykstra, Bright Radical Star: Black Freedom and White Supremacy on the Hawkeye Frontier (Cambridge, MA, 1993). 


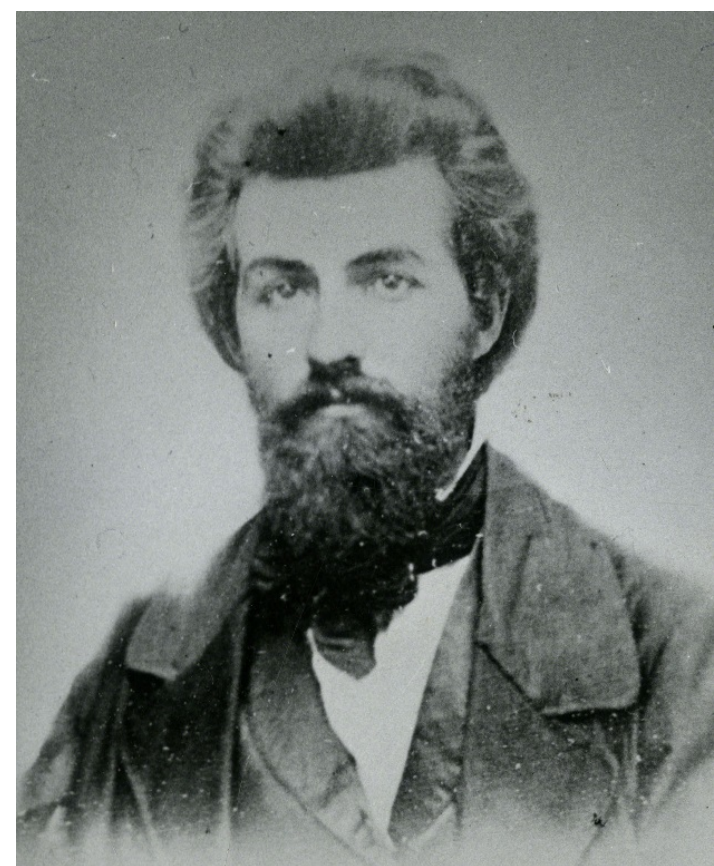

Benjamin Gue (1828-1904). Courtesy Special Collections and University Archives, Iowa State University Library, Ames.

After two terms in the Iowa house and one in the senate, Gue left politics for a brief period and moved to Fort Dodge to take over as editor and publisher of the Iowa North West. In 1865 he returned to the political arena when he was elected lieutenant governor and served one term with Governor William Stone. A tall, angular man with an "exceptionally rich clear far carrying voice," Gue cut an impressive figure on the floor of the state legislature. Charles Aldrich, who served alongside Gue in the legislature, observed upon Gue's passing in 1904, "If one wished what was the right in morals, in business, in politics, he never was disappointed in Gue. He was outspoken, fair, and without guile, trickery, finesse or pretense." 19

19. Des Moines Register and Leader, 6/2/1904. 
In the winter of 1858, Gue, Robert A. Richardson, and Ed Wright, all newly elected members of the Seventh General Assembly, presented a bill to create an agricultural college, which Richardson introduced in February 1858. ${ }^{20}$ Acutely aware of his own limited education, Gue gave an impassioned speech on the bill's behalf. After the original appropriation request was cut in half to $\$ 10,000$, the bill passed..$^{21}$ When, in 1860, opponents of the school sought to repeal the 1858 act establishing the college, Gue again led the fight with a spirited defense as author of a majority report of the agricultural committee. Through some parliamentary maneuvering, Gue was able to table that bill, and it never came up for a vote for the rest of the session. In 1864 friends of the state university sought to have the land-grant money diverted to Iowa City with the condition that a department of agriculture would be established. Gue and his "friends of the college" again squelched that idea, and the entire grant remained secured to the school in Ames. ${ }^{22}$ Thus by the time the college was finally ready to get organized to start its educational mission, Gue had already been involved in several skirmishes with the school's dogged opponents. ${ }^{23}$

After Gue moved to Fort Dodge in 1864 to take over the local newspaper, The Iowa North West, he continued to keep a close eye on the Ames college even as he immersed himself in local affairs. In late 1866 Gue joined IAC's board of trustees, and in January 1867 he agreed to serve as its president. At that same meeting a small committee consisting of Governor William Stone, Gue, and another board member, Peter Melendy, was charged with visiting

20. The early legislative history of IAC is covered in Ross, A History of the Iowa State College, 14-21; Ross, The Land-Grant Idea at Iowa State College, 21-27; and Dorothy Schwieder, "The People's College," in The Land-Grant Act and the People's College, Iowa State University, 27-28.

21. Benjamin F. Gue, “The Origins of Iowa State College: A Founder's Own Account," Annals of Iowa 34 (1958), 342-48. The original manuscript of Gue's speech is in box 2, Benjamin F. Gue Papers, SHSI-DM. Gue's majority report for the agriculture committee is in 1860 Iowa House Journal, 245-46.

22. Report of the Secretary of the Iowa Agricultural College and Farm (n.d., but probably December 1859). This report is appended to the First Report of the Secretary of the Iowa Agricultural College to the General Assembly of the State of Iowa for the Years 1858 and 1859 (Des Moines, 1859).

23. For an account of Story County's efforts to host the college, see W. O. Payne, History of Story County Iowa: A Record of Settlement, Organization, Progress and Achievement, 2 vols. (Chicago, 1911), 1:98-102. 
"Agricultural Colleges in other States, in order to procure all information necessary for the successful organization of our College." The committee's goal was to locate a faculty and president for IAC, a school "designed to be as perfect in organization, and all of its equipments, and of high an order, as any Educational Institute in the West." 24

Like Gue, Peter Melendy played a prominent role in IAC's early years. Born in Ohio in 1823, Melendy was active in raising cattle both on his farm near Cincinnati and then, after moving to Iowa in 1856, on the 1,000-acre farm near Cedar Falls where he would live the rest of his life. As a prominent member of the state's agricultural community, Melendy held numerous offices over the years. From 1858 to 1872 he was a member of IAC's board of trustees. During that period, Governor Samuel Kirkwood appointed him to select the 240,000 acres allocated to the state by the Morrill Act to support the new agricultural college. In January 1865 Melendy agreed to serve as secretary for the fledgling IAC for the coming year and spent 135 days at the model farm, as well as traveling throughout the state acting as an informal early extension agent for the school. From 1865 to 1870, he was also president of the Iowa State Agricultural Society (ISAS). ${ }^{25}$ The ISAShad been an early proponent of the agricultural school, calling

24. Minutes, Iowa Agricultural College Board of Trustees, 1/14/1867 and 1/15/ 1867, Minute Book for 1865-1873, University Archives, Iowa State University Library, Ames; Iowa North West, 10/2/1867. As it turned out, Governor Stone was unable to leave his duties leading the state, so Gue and Melendy ended up doing the committee's work.

25. For Melendy's contribution to the early IAC, see Luella M. Wright, Peter Melendy: The Mind and the Soil (Iowa City, 1943), 200-211. Gue provide a thumbnail sketch of Melendy in History of Iowa from the Earliest Times to the Beginning of the Twentieth Century, 4 vols. (New York, 1903), 4:186-87. Melendy was a consistent advocate for the agricultural college. See, for example, his presidential address to the Iowa State Agricultural Society in September 1865 in Report of the Secretary of the Iowa State Agricultural Society, "September Meeting" (Des Moines, 1866), 42-43. For Melendy's efforts to locate college lands for sale or lease, see Roscoe L. Lokken, Iowa Public Land Disposal (Iowa City, 1942), 169-75. His stockbuying adventures in Ohio are reported in the Cedar Falls Gazette, 1/6/1865, $1 / 27 / 1865$, and 2/3/1865. See also Johanna C. Fedson Kirkman, "A History of Land Grants Used for Education in Iowa" (master's thesis, Iowa State College, 1928), 88-108. For Melendy's observations on the early history of IAC, see "Personal Recollections of Iowa Men and Events," folder 9, box 45, Peter Melendy Papers, SHSI-DM. 


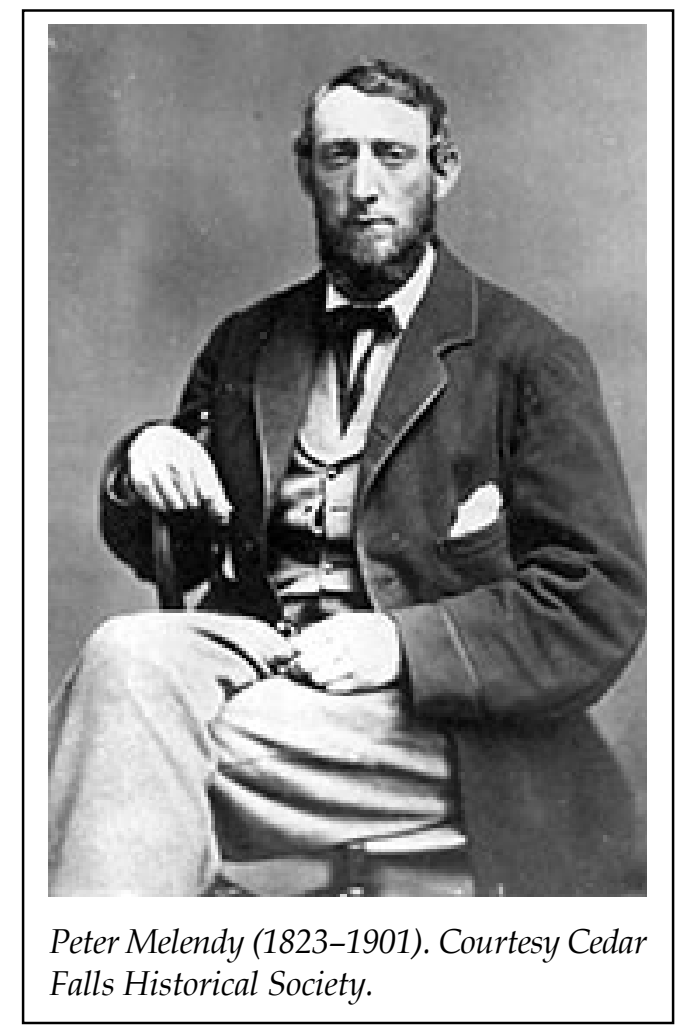

for its creation as early as $1856 .{ }^{26}$ Melendy used his presidency of the ISAS to promote agricultural education whenever he could.

Throughout the first months of 1867 Gue and Melendy corresponded with various agricultural schools, seeking the names of individuals who could be recommended as potential faculty members or as president. They soon realized that letter writing was not an effective approach, so in October 1867 they set out to visit agricultural schools in person to learn firsthand how those institutions conducted their work. In the late 1860s only a handful

26. As early as October 1856 the board of directors of the Iowa State Agricultural Society had recommended that members lobby the Iowa legislature to establish a college of agriculture. Minutes, Iowa State Agricultural Society, 10/9/1856, box 1, Iowa State Agricultural Society Records, SHSI-DM. For a recent history of the ISAS for the period 1855-1865, see Michael M. Belding III, "The Farmers' Millennium: The Ideology of Agricultural Improvement in Iowa, 1855 to 1865" (master's thesis, Iowa State University, 2014). 
of schools like the one in Ames were actually up and running; the most prominent were those in Michigan, Pennsylvania, and Connecticut. The schools in Illinois and in New York at Ithaca were just getting started themselves.

Upon their return in January 1868, Gue and Melendy submitted a lengthy report to the IAC board of trustees about what they had found in their travels. The report provided brief accounts of the organizational schemes of the Massachusetts and Pennsylvania agricultural colleges and Yale's Sheffield Scientific School but devoted nearly 20 pages to detailing the curriculum, labor system, and school rules at the Michigan Agricultural College, the school that Gue and Melendy believed represented the ideal template for an agricultural college. ${ }^{27}$

In the conclusion of their report, Gue and Melendy listed a large number of institutions they had visited and people they had met, including Andrew White and Ezra Cornell. Gue's daughter recounts that Cornell had invited her father to Ithaca, where "details of developing a land grant college were discussed at length with great benefit to the inexperienced man from a pioneer state." 28 In addition to visiting Cornell University and the agricultural colleges in Massachusetts and Pennsylvania, the Iowans spent time at Harvard University, Amherst College, the Smithsonian Institution in Washington, D.C., Farmers' College in Ohio, the School of Mines in New York City, and the Agassiz Museum in Cambridge, Massachusetts, to name just of few of their stops. At each institution, they met with the chief presiding officer as well as prominent faculty members. Gue and Melendy noted that the mass of information obtained was too extensive to include in their

27. The IAC Board of Trustees minutes for January 15, 1868, briefly mention that the Gue/Melendy report had been presented, but the text of the report is not found in the minutes. For the full report, see "Report of the Committee on Organization, and Selection of Faculty," in the Second Report of the Trustees of the Iowa Agricultural College, to the Governor and General Assembly of Iowa (Des Moines, 1868), 25-62 (hereafter cited as "Report of the Committee on Organization"). For histories of the Michigan agricultural college, see W. J. Beal, History of the Michigan Agricultural College and Biographical Sketches of Trustees and Professors (East Lansing, MI, 1915); and Keith R. Widder, Michigan Agricultural College: The Evolution of a Land-Grant Philosophy, 1855-1925 (East Lansing, MI, 2005).

28. "Report of the Committee on Organization," 57; Katherine Leonard Gue, "Notes on the Life of Benjamin F. Gue." 
summary report but would be "invaluable in the organization, furnishing, fitting up and inaugurating our college." 29

In their report, Gue and Melendy failed to mention Gue's remarkable chance meeting with Justin Morrill. William Brewer, who for many years taught agricultural courses at Yale's Sheffield School of Science, later recounted the meeting that Morrill had with members of the Sheffield School faculty in November 1867. Brewer noted that among the men meeting at Daniel Gilman's house on the evening of November 11 was Benjamin Gue, "who chanced to be here visiting our school and who was glad of the opportunity thus to meet Mr. Morrill." Gue must indeed have been pleased that he happened to be in New Haven on the same evening that the author of the land-grant act showed up. ${ }^{30}$

The group questioned Morrill "as to his own intentions" as well as the views of other congressmen who worked on his bill. Morrill responded bluntly that he never intended the land-grant institutions to be agricultural schools. He noted that a clerk was responsible for the bill's title. For Morrill, the most important aspect of his bill was that the "teaching of science should be the leading idea." Moreover, he wanted the "useful sciences" to be taught. He was adamant that the teaching of science should take precedence over the teaching of agriculture; he was less concerned about whether a participating college had a farm attached to it. In addition, at a time when manual labor programs were being taken up enthusiastically by the new western colleges, Morrill

29. "Report of the Committee on Organization," 56-57. It is unfortunate that the vast amount of material gathered by Gue and Melendy has not survived. Their excursion included visits to some of the most significant institutions of higher learning - both land-grant and traditional - in the country along with conversations with some of the leading educational figures of the day. The data they collected and the observations they recorded would have represented a remarkable picture of the state of higher education in the mid-1860s.

30. William Brewer, "The Intent of the Morrill Land Grant," folder 299 ("Morrill Land Grant"), box 45, William Brewer Papers, Manuscripts and Archives, Yale University Library, New Haven, CT. Brewer wrote up his notes in the late 1880s, and then typed them up in 1908 when he was clearing out his office at Yale. For more on the Yale school, see Russell H. Chittenden, History of the Sheffield Scientific School of Yale University, 1846-1922, 2 vols. (New Haven, CT, 1928). Gue evidently provided an account of his visit to Ithaca and New Haven in the November 27, 1867, and December 18, 1867, issues of the Iowa North West. Unfortunately, those issues are no longer extant. 
was less than enthusiastic about manual labor training and did not see it as having much educational value for students. ${ }^{31}$

For Gue, Morrill's views were probably somewhat disconcerting, since both he and Melendy were strongly committed to the agricultural emphasis that they envisioned for IAC's curriculum. They also believed in the importance of manual labor as an integral part of the college's educational experience. ${ }^{32}$ Given their disagreement with some of Morrill's opinions (and also because Morrill had spoken in confidence), they decided not to mention Gue's meeting with the great man in their report to the IAC board of trustees.

IAC's curriculum would evolve over the months following Gue and Melendy's report to the board in January 1868. Initially, Gue and Melendy recommended the following courses for the new school:

Natural Philosophy, Chemistry, Botany, Forestry, Horticulture, Fruit-growing, Animal and Vegetable Anatomy and Physiology, Geology, Mineralogy, Meteorology, Entomology, Zoology, Veterinary Art, Plain Mensuration, Leveling, Surveying, Book-keeping, Practical Agriculture, Landscape Gardening, with other such branches as may be added by the Faculty and Trustees. ${ }^{33}$

31. Brewer, "The Intent of the Morrill Land Grant." Morrill expanded on his rationale for promoting the land-grant act in the years after the act's passage. His most extensive comments are found in Justin S. Morrill, The Land-Grant Colleges: An Address Delivered at the Eighty-Ninth Commencement of the University of Vermont and State Agricultural College, June 28th, 1893 (Burlington, VT, 1893), and in Massachusetts Agricultural College, Addresses Delivered at the Massachusetts Agricultural College, June 21st, 1887, on the 25th Anniversary of the Passage of the Morrill Land Grant Act (Amherst, MA, 1887), 17-26. On the enthusiasm of midwestern colleges of the time for manual labor programs, see Kenneth $\mathrm{H}$. Wheeler, Cultivating Regionalism: Higher Education and the Making of the American Midwest (DeKalb, IL, 2011), 26-43.

32. Melendy summarized his views (and probably those of the rest of the IAC board) in his January 1,1866, "Report of the Secretary of the Iowa Agricultural College and Farm." This document has no publisher or publication date, but is contained in Legislative Documents Compiled by Order of the Eleventh General Assembly of the State of Iowa, which Convened in Des Moines, January 8, 1866 (Des Moines, 1866).

33. "Report of the Committee on Organization," 60. Earlier in their report, Gue and Melendy reproduced the Michigan Agricultural College curriculum for probably 1866 or 1867 (they did not specify which year). 
For the most part, these were the same courses that were taught at the Michigan institution. The Iowans did, however, omit some subjects that were included in the Michigan catalog: history, English grammar and composition, moral philosophy, inductive logic, civil engineering, and French. ${ }^{34}$ Some of these differences would be resolved in the first IAC catalog in 1869. One major reason for that was the hiring of Adonijah Welch as the college's first president.

FROM THE OUTSET a top priority for the IAC board was to find a president who could in turn hire a well-respected faculty. In their report, Gue and Melendy placed Adonijah Welch at the top of their list of potential presidents. Welch had come to Gue's attention because of his long association with education in Michigan. Gue set out in early 1868 to recruit Welch, who at the time was living in Florida and would soon be chosen to serve a truncated term as U.S. senator from that southern state.

Adonijah Strong Welch was born in 1821, the eldest child of Bliss and Elizabeth Welch, and grew up on their farm near East Hampton, Connecticut. Recognizing that the new university in Ann Arbor, Michigan, might afford him a quality education, at age 18 Welch enrolled in a preparatory academy in Romeo, Michigan, then entered the university's sophomore class, and graduated in 1846. At Michigan, Welch received a typical college education for the period, with heavy emphasis on the classics and a sprinkling of mathematics and natural science. After acquiring his undergraduate degree, he studied law in Detroit and was admitted to the Michigan bar. He never practiced law, however, but instead took his first educational position as principal of the first graded school in Jonesville, Michigan, about 60 miles southwest of Ann Arbor. ${ }^{35}$

34. Ibid., 30-32. The 1871 catalog, which had changed little from what Gue and Melendy reported, is reproduced in Beal, History of the Michigan Agricultural College, 69-70. See also, for another example, the 1869 catalog in Catalogue of the Officers and Students of the State Agricultural College (Lansing, MI, 1869).

35. Biographical sources on Welch are limited; see Ross, A History of the Iowa State College, 59-60; Dictionary of American Biography (New York, 1936), 19:617-18; National Cyclopaedia of American Biography (New York, 1904), 12:291; American National Biography (New York, 1999), 22:919-21; and David Hudson, Marvin Bergman, and Loren Horton, eds., The Biographical Dictionary of Iowa (Iowa City, 
The Jonesville Union School opened its doors in January 1848 under the leadership of Welch and two assistants. Its curriculum was designed to match the course offerings available at private academies or select schools. The school's primary goal was to train teachers for the common schools and also prepare young men and women for college. Courses taught included algebra, geometry, chemistry, Latin and Greek, and even Spanish. ${ }^{36}$ Welch served as director from 1847 to 1849 . After ill health forced him to resign, he ventured out to the California gold fields, where he enjoyed more hospitable weather and a chance to mine for gold. ${ }^{37} \mathrm{He}$ did not strike it rich in California, but he did come down with typhoid fever. By early 1851 his health was restored, and he returned to Jonesville to resume his duties as director.

In October 1852 he was named the first principal of the newly created Michigan State Normal College in Ypsilanti; classes officially started in March 1853. At the time, there were no such schools west of Albany, New York, and only three states had them at all. In anticipation of the new school's opening, Welch conducted two teachers institutes for local teachers. The institutes were popular and soon led to the founding of the State Teacher's Association with Welch as that body's first president.

2008), 548-49. Additional material can be found in folder 1 ("Biographical Information"), box 1, Adonijah S. Welch Papers, University Archives, Iowa State University Library, Ames. The early University of Michigan curriculum is described in Howard H. Peckham, The Making of the University of Michigan, 18171967 (Ann Arbor, MI, 1967), 22-23.

36. Charles R. Starring and James O. Knaus, The Michigan Search for Educational Standards (Lansing, MI, 1969), 35-36. For brief histories of the Jonesville School, see Ralph Monroe Powers, Jonesville Union School at Jonesville Hillsdale Co. Michigan (Jonesville, MI, 1876, reprinted in 2008); and History of Hillsdale County, Michigan, with Illustrations and Biographical Sketches of Some of its Prominent Men and Pioneers (Philadelphia, 1879), 139-42.

37. Welch's accounts of his experiences in California were published in Wisconsin and Michigan newspapers. His letters were published in the Milwaukee Sentinel and Gazette in 1849 and 1850 and reproduced a century later in William H. Hermann, ed., "Three Gold Rush Letters of Adonijah Strong Welch," Iowa Journal of History 57 (1959), 61-73. See also "The Fayette Rovers as Recorded by A. S. Welch," folder 3 ("Biographical Information"), box 1, Welch Papers. The Fayette Rovers account appeared in the Hillsdale Whig Standard, 12/11/1849. Welch's diary and travel account also inform Edward Leo Lyman's The Overland Journey from Utah to California: Wagon Travel from the City of Saints to the City of Angels (Reno, NV, 2004). 
In remarks at the October 1852 teachers institute, Welch explained his basic teaching philosophy, a philosophy that would remain with him for the duration of his professional career.

No amount of text-book knowledge, as such - no memory of straggling undigested facts or details-no skimming of the area of knowledge of whatever sort, can make the genuine scholar or independent thinker. It is rather by investigating the relations of facts and things - by a close scrutiny of the reasons on which opinions are founded - by a rigid analysis of every subject brought before his attention - that the student, at last, attains to a genuine cultivation of intellect.

Welch added that the most important task of any school was to assist its charges in securing "a symmetrical development of intellect," by making "proportionate attainments in the various departments of knowledge." 38 For Welch, the best education provided a balanced curriculum with equal attention to literature, the arts, mathematics, and the sciences. That view would undergird Welch's thought and actions both in Ypsilanti and in Ames.

The normal school established two separate curricula for its prospective teachers. The English course, lasting two years and designed for teachers in the lower primary grades, consisted of instruction in various aspects of the English language, geography, geology, algebra, geometry, trigonometry, anatomy, physiology, and chemistry. The classical course required an extra year of coursework and included a good amount of Latin and Greek in addition to the subjects taught in the English course. Both programs contained a capstone course on the theory and practice of teaching. ${ }^{39}$ Welch ran a tight ship as principal, making sure his

38. Annual Report of the Superintendent of Public Instruction and Accompanying Documents Made to the Legislature for the Year 1853 (Lansing, MI, 1853), 127 (emphasis in the original). Welch's remarks given upon becoming principal at the Normal School are also printed ibid., 81-85. Histories of the normal school include the standard account of the first half-century by Daniel Putnam, A History of the Michigan State Normal School (Now Normal College) at Ypsilanti, Michigan, 18491899 (Ypsilanti, MI, 1899). Also useful are Ebert R. Isbell, A History of Eastern Michigan University, 1849-1965 (Ypsilanti, MI, 1971); and Ronald Flowers, The Michigan State Normal School and the Preparation of Teachers: A History and Institutional Analysis (Saarbrüchen, Germany, 2008).

39. Putnam, A History of the Michigan State Normal School, 39-40. See also Isbell, History of Eastern Michigan University, 13-21, 109-12. A course catalog for 1858 provides more detail: Catalogue of the Officers and Students of the Michigan State 
pupils focused on what was important. One former student remembered Welch years later as "the most rigid disciplinarian in the school room that I ever knew. His compressed and quivering lip was to the luckless transgressor an omen of impending calamity not to be mistaken or misunderstood. It was a fearful foreboding of vigorous corrective treatment." Another young scholar recalled that, as a teacher, Welch was "of deliberate, intense thought, his principles being easily grasped by his students." 40

As Welch's rather frail constitution failed, he decided in 1865 to move to Jacksonville, Florida, where he and his brother-in-law jointly purchased "a hundred acres of land, built a sawmill, planted oranges and thought they had bright prospects." His years in Florida quickly soured as his first wife and then his brother-in-law both died suddenly. During that period, Welch became actively involved in the chaotic Reconstruction-era Florida politics and was chosen to chair the state Republican Party. The upshot was that on June 17, 1868, the Florida legislature elected Welch, despite his lack of political experience, to serve as U.S. senator to fill out the short term that would expire on March 3, 1869. Meanwhile, in February 1868 Welch had also found time to remarry, this time to Mary Beaumont Dudley, a widow whose husband had been on the faculty of the Michigan Normal School while Welch was principal there. ${ }^{41}$

Normal School for the Year 1857-1858 (Detroit, 1858). For a general overview of the development of both the normal school and the agricultural college, see Willis F. Dunbar, The Michigan Record in Higher Education (Detroit, 1963), 83-102.

40. C. F. R. Bellows, "Reminiscences: The Early Days of the Normal School," in Michigan State Normal School, Proceedings of Anniversary Day Exercises, Thursday, March 28, 1895 (Ypsilanti, MI, 1895), 8-9; The Normal News 15 (March 1896), 6.

41. The quote about Welch and his business prospects is from a letter Arvin Benjamin Shaw wrote to Edgar Stanton in 1940, folder 5 ("Correspondence on Welch Family"), box 1, Welch Papers. The Weekly Floridian, 6/23/1868, noted Welch's election as senator on June 17. On Florida's political scene during this period, see Jerrell H. Shofner, Nor Is It Over Yet: Florida in the Era of Reconstruction, 1863-1877 (Gainesville, FL, 1974), 177-97; idem, "Political Reconstruction in Florida," Florida Historical Quarterly 45 (1966), 145-70; idem, "Florida: A Failure in Moderate Republicanism," in Reconstruction and Redemption in the South, ed. Otto H. Olsen (Baton Rouge, LA, 1980), 13-46; and William Watson Davis, The Civil War and Reconstruction in Florida (1913; reprint, Gainesville, FL, 1964), 53132. For a bit more on the skirmishing that led to Welch's selection, see Canter Brown Jr., Ossian Bingley Hart: Florida's Loyalist Reconstruction Governor (Baton Rouge, LA, 1997), 218. Brief biographies of Mary Welch can be found in Ercel 
As Welch was busy with Florida politics, Gue was at the same time pursuing him for the presidency of IAC. When Gue and Melendy were at the Michigan Agricultural College during the fall of 1867, they learned of Welch from President Theophilus Abbott. Welch had served from 1863 to 1866 on the Michigan State Board of Agriculture, the governing body of the school outside Lansing. Abbott assured his Iowa visitors, "If you could get A. S. Welch, he is the best man in America to organize your college." 42 The IAC board of trustees had been clear in its instructions to Gue and Melendy: their leader "must be a man clearly comprehending the plan and objects of an agricultural college, who is in full sympathy with its friends, and a firm believer in the idea." 43

Gue corresponded with Welch on April 10, asking if he would consider the presidency of the Ames college. On May 1 Welch replied that he would accept the offer if the board elected him unanimously. At its meeting on May 11, 1868, the board did unanimously support the nomination of Welch as president. At the same meeting, after vigorous debate, the board voted 9-3 to allow women as students. Gue and Melendy led that fight and succeeded in bringing along a majority of the board. It helped that the State University of Iowa had admitted women from the outset. ${ }^{44}$

Sherman Eppright and Elizabeth Storm Ferguson, A Century of Home Economics at Iowa State University: A Proud Past, a Lively Present, a Future Promise (Ames, 1971), 10-11; and Hudson et al., eds., Biographical Dictionary of Iowa, 549-50.

42. Gue mentions Abbott's recommendation in his remarks at Welch's funeral, reproduced in the Aurora 18 (April 1889), 6-9. Welch's service on the Agricultural Board is noted in Beal, History of the Michigan Agricultural College, 346-47.

43. "Report of the Committee on Organization," 27.

44. Minutes, IAC Board of Trustees, 5/11/1868. In the footnotes to the published version of his remarks at Welch's funeral (The Aurora 18 [April 1889], 6-7), Gue alludes to his correspondence with Welch about the position. There is no record of that correspondence in the archives. Gue's views on including women in the college were informed by a trip he took in March 1868 along with his newspaper partner, Nelson M. Page, to Illinois, Michigan, and Ohio, where they visited Oberlin and Antioch colleges. Both colleges were at the forefront of including women as students equal to men. Gue noted in his newspaper that Antioch College had broken away from "the old fossilized notion that white boys alone were ordained to be the only recipients of a thorough education and that girls and colored boys had no rights inside of College walls. It has labored most successfully to demonstrate that religious instruction need not be sectarian, but might and should be in Educational institutions, comprehensive, pure, free from bigotry and narrow and cramped sectarian bounds and forms, that 
Thus, by mid-May 1868, Welch knew that he would be the new president of IAC. Yet he also allowed his name to be put forward in Florida as U.S. senator for the short term that would run from June 1868 to March 1869. One wonders why Welch agreed to the Senate term, since by March 1869 he would no longer be a Floridian. Whatever his reasons, 1868 would be a busy year for Welch as he assumed the role of U.S. senator while at the same time undertaking the daunting task of organizing and launching a new agricultural college in Ames.

IN SEPTEMBER 1868 Welch and his wife and children traveled from the Ames train depot in "a big lumber wagon that was sent to escort in state, the president of the Iowa Agricultural College from Ames to his new home. Only half of the Main Building was completed, the wings being added later, and it was set in a broad expanse of rough, unbroken prairie." 45 The Welch family spent its first night in the "rudely-furnished, unscrubbed hospitality of the Farm House." 46

Now on the job, Welch was aware of the challenges before him and knew that the college "must organize, at the start, a library, museum, cabinets, laboratories, and must equip, at once, a workshop with all its machinery, a garden, vineyard and orchard, and a farm with its full supplies of buildings, implements, vehicles and fine stock, the whole to be conducted so as to illustrate the latest and best methods, and above all, a corps of competent professors must be gathered from the four corners of the earth, must just suit a new latitude and fall into line without confusion." 47

too often mar and deform beauties and truths." The same issue of the Iowa North West published a letter written by Gue from Detroit on March 24, 1868, confirming that Welch, a man "so highly recommended by leading men of the State," would be nominated for president to the IAC board of trustees. The North West, 4/8/1868 (emphasis in the original).

45. From an account by Welch's stepdaughter Winifred Dudley Shaw, in History and Reminiscences of I.A.C. (Des Moines, 1897), 113.

46. Robert T. Hilton, Education for Pioneers and Pioneers in Education (Ames, [1965]), 2.

47. "Address by President Welch," in Annual Report of the Iowa State Horticultural Society for 1874, Being the Proceedings of the Ninth Annual Meeting, Held at Burlington, January 19, 20, and 22, 1875 (Des Moines, 1875), 154. 
That was a tall order indeed, but Welch had already done similar work in his stint at Ypsilanti in the 1850s. In mid-September he assured Gue that he was "working steadily at my report," which would outline the college's path forward. 48

In October 1868 Welch finished drafting his organizational plan for IAC. Although Gue and Melendy had favored the curriculum as taught at the Michigan Agricultural College, Welch brought his own perspective to his assignment. As a grammarian who a dozen years earlier had published a 264-page study of the English sentence, Welch had carefully scrutinized the text of the Morrill Act and concluded that the "principal clause announced in precise English" that agriculture and the mechanic arts would by law be the leading subjects taught at any school accepting the grant. He observed that the law would permit the teaching of scientific and classical studies not connected with agriculture or the mechanic arts to round out the curriculum, but, he added, "The creation of a department of general science and literature which should overshadow the departments essential to the enterprise, would be a manifest violation of the spirit and intent of the national law." To Welch, the way forward was clear: the college would have two distinct academic tracks, one in agriculture and the other in mechanic arts; military tactics and other associated scientific and classical studies would be allowed, but would remain subordinate to the two main disciplines. ${ }^{49}$

For the first year-and-a-half, all IAC students would adhere to the same course structure. Algebra and geometry, physical geography, physiology and hygiene, as well as general chemistry, botany, and mensuration and surveying represented the basic sciences. The humanities were reflected in the subjects of rhetoric

\footnotetext{
48. Welch to Gue, 9/15/1868, folder "Correspondence 1836-1901," box 1, Gue Papers, SHSI-DM.

49. Welch's grammar text is Analysis of the English Sentence, Designed for Advanced Classes in English Grammar (New York, 1855). For the quotes, see Welch, Plan of Organization of the Iowa State Agricultural College, Ames, Story County, Presented by A. S. Welch, President Elect, to the Board of Trustees, October 21, 1868. Adopted by the Committee on Organization (Des Moines, 1868), 1-2, file folder 1/11 ("Plan of Organization of the Iowa State Agricultural College"), box 1, Welch Papers. For a general history of curricular development in colleges, see Frederick Rudolph, Curriculum: A History of the American Undergraduate Course of Study Since 1636 (San Francisco, 1977).
} 
and English language and literature. Perhaps surprisingly to contemporary readers, the subject of bookkeeping was introduced in the first semester, reflecting the strong belief by many agricultural thinkers of the time that efficient record keeping was important as a way for farmers to keep track of how well their farms were working. Farming was a way of life, but it also was a business and required business methods for smooth operation. ${ }^{50}$

By the second half of the second year, the students began their specialized training in either agriculture or mechanic arts. The agriculturalists studied soils, entomology, analytical and agricultural chemistry, practical agriculture, landscape gardening, and rural architecture, while the students in the mechanic arts track engaged in the study of engineering, calculus, architectural and mechanical drawing, principles of architecture, and carpentry and masonry.

In the last semester of the fourth year all students came together for instruction in mental philosophy and constitutional law before splitting up again for courses in veterinary science and art or civil engineering. Welch added that students could take courses in French and German as well as music and free-hand drawing outside the prescribed curriculum. ${ }^{51}$ Nowhere was there any mention of Greek or Latin. Those vestiges of the old-fashioned college course offerings would not be included in a landgrant college curriculum. Even the teaching of history, which had been included in the courses offered at the Michigan Agricultural College, was not part of IAC's course schedule. Finally, the inclusion of mental philosophy, or what we would today call psychol-

50. Alan I Marcus, Agricultural Science and the Quest for Legitimacy: Farmers, Agricultural Colleges, and Experiment Stations, 1870-1890 (Ames, 1985), 17-18. For more on various school course schedules, see the valuable collection of landgrant school curricula found in Part 2, "Colleges, Schools, and Departments of Agriculture and the Mechanic Arts," in Report of the Commissioner of Education, with Circulars and Documents Accompanying the Same; Submitted to the Senate and House of Representatives, June 2, 1868 (Washington, DC, 1868), 215-309.

51. Welch, Plan of Organization, 5-6. This curriculum is reprinted in Third Biennial Report of the Board of Trustees of the State Agricultural College and Farm to the Governor of Iowa and the Thirteenth General Assembly, January 1870 (Des Moines, 1870), 10-11. For a summary of Welch's educational philosophy, see his address to the Iowa State Horticultural Society in January 1875 in Annual Report of the Iowa State Horticultural Society for 1874, Being the Proceedings of the Ninth Annual Meeting, Held at Burlington, January 19, 20, and 22, 1875 (Des Moines, 1875), 148-60. 
ogy, appeared in the last semester. Welch had a special affinity for this area. Late in his career he would publish a thick tome on the psychology of teaching. ${ }^{52}$ From the fall of 1871 forward, the mental philosophy course name was changed to psychology.

All in all, the curriculum at IAC was relatively simple, straightforward, and focused closely on agriculture and the mechanic arts. In its simplicity it would provide "a more useful, practical and business education, suited to every-day life of nearly every man." 53

After submitting his curriculum to the IAC board of trustees, Welch, before returning to Washington, remained in Ames for a few weeks to attend to a myriad of details associated with the start of classes. In his "Plan of Organization," Welch had called for hiring 18 faculty. Before classes officially started in March 1869 , the IAC board believed it necessary to provide a preparatory term in October 1868 to help new potential students succeed with college-level work. For this preparatory term, which enrolled 61 students (54 men and 7 women), Welch had so far hired only three full-time instructors in addition to himself. Norton S. Townsend would be the first professor of practical agriculture at IAC. He was from Ohio and had attended medical school, served as an army surgeon during the Civil War, and after the war occupied a seat in the Ohio legislature. He had been a member of the Ohio State Board of Agriculture and was deeply interested in promoting agricultural education. George Jones, an 1859 Yale graduate, was a mathematical whiz and had taught most recently at the Franklin Institute in New York. Finally, for the area of chemistry, Welch hired Albert E. Foote at the age of 22. Foote had studied at Courtland Academy in New York, followed by study at Harvard and the University of Michigan, where he had earned a medical degree. These three men plus Welch would be the instructional core of IAC during its first years. ${ }^{54}$

52. Welch, The Teachers' Psychology: A Treatise on the Intellectual Faculties, the Order of Their Growth, and the Corresponding Series of Studies by Which They Are Educated (New York, 1889). A year earlier Welch had published a shorter work titled Talks on Psychology Applied to Teaching: For Teachers and Normal Institutes (New York, 1888).

53. William Duane Wilson, A Description of Iowa and Its Resources in Which Every County in the State Has Separate Mention (Des Moines, 1865), 96.

54. Ross, A History of Iowa State College, 61; Welch, Plan of Organization, 15-17. 


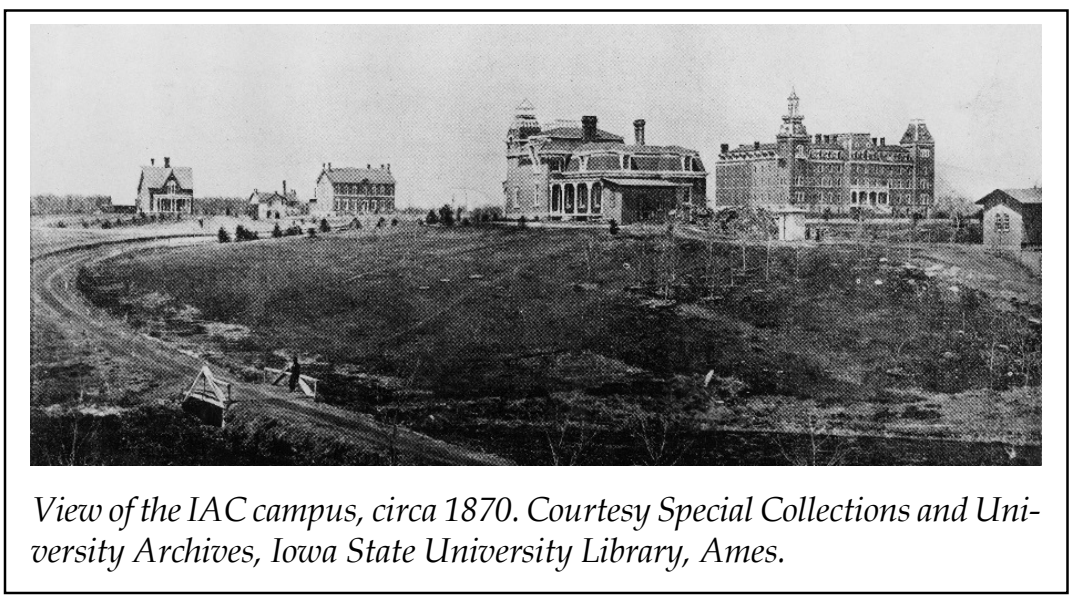

BY MARCH 1869, the Iowa State Agricultural College and Model Farm was ready to start formal classes. The faculty and other staff had been hired, the preparatory classes had concluded in December, and Welch had completed his term as senator as of March 3. Main Hall was for the most part completed, and 173 incoming students - 136 men and 37 women-were officially enrolled for the first semester of full-time coursework.

On the morning of March 17 a large crowd, numbering perhaps as many as 1,200 , appeared on the barren campus west of the village of Ames to witness the inauguration ceremonies of the new college. ${ }^{55}$ Benjamin Gue spoke first, remarking that where the crowd now stood, not that many years before there had been "nothing but a great prairie farm, wild, but beautiful in its wildness, remote from railroad, river, cities or towns, it seemed far better adapted for the quiet retreat of some pioneer farmer and backwoods hunter, than for a site upon which to erect a College for the children of farmers and mechanics of a great State." But there now existed an institution, one for which Gue had provided an affectionate and guiding hand over the first decade of its existence. The state of Iowa now had, Gue asserted with pride, an institution within reach of young Iowans of moderate means, one where a thorough education could be combined with the

55. For a contemporary account of the IAC inauguration, see Iowa Homestead, 3/26/1869, 92. 
practical knowledge of the sciences "illustrated in the field and workshop." The course of instruction at IAC "must be eminently practical" with no time squandered on the dead languages of the past. Its mission was to provide to its students "a more thorough knowledge of the natural sciences, and useful arts." Finally, Gue assured his listeners that one of IAC's chief aims would be to open its doors to "any of God's people, whether high or low in social circles, rich or poor, white or black, man or woman." Gue was a staunch supporter of women in higher education and had stubbornly insisted that they be included alongside men when IAC opened. As he gazed out over the assembled group, Gue was comforted that having "already passed through the stages of doubt, ridicule, reproach, slander, ignorant fault finding, and malicious misrepresentation, unscathed" he could look forward with confidence that the new institution would thrive and grow. ${ }^{56}$

With the keys to the newly constructed Main Building in hand, Welch stood up to deliver his inaugural address. He divided his speech into two parts. The first dealt with the importance of practical education versus the traditional one based on the classics. Noting the desirability of leaving behind a curriculum obsessed with "the dead Past," Welch urged his listeners to appreciate the importance of studying the natural sciences and how such study would benefit the young and formative minds of IAC's students. "The immense vocabulary which their nomenclature has made, can never be encompassed without a powerful exertion that renders the memory ready and retentive." Welch believed that investigating the various disciplines associated with the sciences in both agriculture and the mechanic arts - would "keep the reflective faculties in a state of constant tension." After spending a great deal of time touting the significance of the applied sciences, toward the end of his first section Welch also affirmed that "political economy, social science, commercial and constitutional law, and moral philosophy, are a harmonious and beautiful group; and if we combine with these our own language and literature, we have variety enough with which earnestness of study can

56. Addresses Delivered at the Opening of the Iowa State Agricultural College, March 17, 1869 (Davenport, 1869), 5-15. 
preserve the desirable breadth and balance of culture." 57 During the early years of his presidency, Welch would face repeated challenges from those outside the college who believed that teaching anything not directly related to agriculture and the mechanic arts was unacceptable. William Wynn, a longtime IAC faculty member, remembered later that Welch jealously guarded the "whole of that side of the curriculum embracing Languages, Literature, History, Intellectual and moral sciences, etc." 58

Welch ended his address with an extensive discussion of why women should not be barred from attending colleges and universities. His entire educational experience had included schools that accepted both genders in the classroom, so, for Welch, the question of women in college had long been settled. For those hearing his remarks that March morning, Welch made it clear that "the mental capacities of women are the same in number with those of man." Welch pointed to a number of women who had performed as well as men in their chosen fields, such as the French writer Madame de Staël, the American astronomer Maria Mitchell, or even the military leader Joan of Arc. Welch was confident that, given a chance at more education, many more women could make equivalent contributions. Moreover, he assured his listeners, "In twenty-five years of personal observation in the charge of promiscuous schools, I have found the female student fully equal to the male in capacity for thoroughness in any of the branches of study, whether common or higher." For Welch, the admission of women to IAC was simply a foregone conclusion, one that had already been reached at Oberlin College and the State University of Iowa and would within a few years become the norm at most institutions of higher learning. ${ }^{59}$

Finally, ten years after it had been created, the Iowa Agricultural College and Model Farm was ready for its students. Gue

57. Welch's inaugural address is printed in Addresses Delivered at the Opening of $I A C, 22-40$ (quotes from pp. 25 and 27).

58. William H. Wynn, “Hon. Adonijah Strong Welch, L.L.D., First President of Iowa State College of Agriculture and the Mechanic Arts-An Estimate" (undated), folder 1 ("Biographical Information"), box 1, Welch Papers. See also Welch's comments in "The True Work of National Industrial Schools," Proceedings of the Fifth Annual Session of the National Agricultural Congress, at Philadelphia, PA., September 12th, 13th, and 14th, 1876 (Chicago, 1877), 38-41.

59. Addresses Delivered at the Opening of IAC, 37-39. 
and Melendy's hard work had paid off: the school now had a curriculum, thanks to the one honed and polished at the Michigan Agricultural College; it had a small group of dedicated faculty; and it had a president whose vision of what a land-grant college could become would blend the practical-oriented approach most favored by Iowa farmers with Welch's own more nuanced view, which included more traditional liberal arts subjects as well. 